\title{
THE LIABILITY OF A DRILLING CONTRACTOR*
}

The facts presented for the purposes of this paper are as follows: Oil operator $\mathrm{C}$ hired a drilling contractor $\mathrm{D}$ as an independent contractor to drill a well for the purpose of obtaining production of oil and gas. During the course of drilling the well, while D was carrying out an inherently dangerous act, an explosion took place which resulted in loss of the hole, loss of the drilling rig, and loss of a third party's nearby equipment.

Six separate questions are based on these facts, along with certain other facts which were added for the purposes of questions five and six. These questions are as follows:

(1) Assuming $\mathrm{D}$ was not negligent in carrying out the inherently dangerous act, what liability arises-with regard to D?-with regard to $\mathrm{C}$ ?

(2) Assuming $\mathrm{D}$ was negligent, what liability arises-with regard to $D$ ? - with regard to $C$ ?

(3) What conditions are essential to ensure that $D$ will be accorded the status of an independent contractor?

(4) Give some examples of drilling, testing or completion operations that you would consider to be inherently dangerous acts.

(5) M, C's invitee, was on the derrick floor and was killed in the explosion. Who was liable for his death? What difference would it make if $M$ was D's invitee?

(6) On the instructions of Sneak Company, a trespasser scout was under the derrick floor and was also killed in the explosion. Who is liable for his death?

The basic purpose of this paper is to examine the relationship of employer-independent contractor and its application in the oil and gas industry to the relationship that exists between an oil well operator and a drilling contractor. A reading of the above questions will show that the problem is presented in the light of various types of liability, for example, strict liability, liability with regard to inherently dangerous chattels, and occupiers' liability.

Prior to dealing with the specific questions set out above, we wish to comment briefly on the law under the following general headings:-

\section{A. LIABILITY GENERALLY}

Generally speaking, liability rests on fault, that is, on the concept of actionable negligence. The components of a cause of action for negligence are: a duty recognized by law, a breach of that duty, and damages flowing from that breach.

The classic statement of the law setting out the relationship between persons that gives rise to such duty is that of Lord Atkin in the case of Donoghue v. Stevenson:

- This paper was prepared through the combined efforts of D. C. Prowse, Q.C., Fenerts \& Co.. Calgary; R. C. Muir, Solicitor, British American Oil Company Limited, Calgary, Murray F. Mackintosh, Solicitor, Hudson's Bay Oil \& Gas Co. Ltd., Calgary; R. R.

Mahaffey, Solicitor, Callfornla, Standard Company, Calgary; D. O. Sabey, Chambers, Saucler \& Co., Calgary; W. B. MacInnes, Lougheed, Ballem, McDill \& MacInnes, Calgary; and J. L. Fingarson, Fenerty \& Co., Calgary. 
The rule that you are to love your neighbour becomes, in law, you must not injure your neighbour; and the lawyer's question, Who is my neighbour? receives a restricted reply. You must take reasonable care to avoid acts or omissions which you can reasonably foresee would be likely to injure your neighbour. Who, then, in law is my neighbour? The answer seems to be-persons who are so closely and directly affected by my act that I ought reasonably to have them in contemplation as being so affected when I am directing my mind to the acts or omissions which are called in question.1

The consideration of whether or not any given conduct amounts to a breach of that duty, once a duty is established, involves a consideration of the concept of the standard of care which the law establishes. It will be appreciated that "the risk reasonably to be perceived defines the duty to be obeyed."

The principle was expanded on by Lord Atkin at another portion of the Donoghue case where he stated at page 596:

The nature of the thing may very well call for different degrees of care, and the person dealing with it may well contemplate persons as being within the sphere of his duty to take care who would not be sufficiently proximate with the less dangerous goods; so that not only the degree of care but the range of persons to whom a duty is owed may be extended. ${ }^{3}$

On the other hand, "people must guard against reasonable probabilities, but they are not bound to guard against fantastic possibilities."4

Assuming a duty, breach and some damages, the further question that arises is whether the damages are recognzied in law as flowing from the breach; the question of remoteness of damage. In this regard we refer you to Overseas Tankship v. Mort's Dock.

\section{B. EXCEPTIONS TO THE GENERAL RULES WITH REGARD TO LIABILITY.}

Under this heading we propose to deal with the rule in Rylands v. Fletcher, ${ }^{6}$ and to comment on the Court's attitude toward liability for inherently dangerous chattels and extra hazardous operations. In the course of his judgment in Rylands v. Fletcher, Blackburn, J. stated:

We think that the true rule of law is, that the person who for his own purposes

brings on his lands and collects and keeps there anything likely to do mischief

if it escapes, must keep it in at his peril, and, if he does not do so, he is prima

facie answerable for all the damage which is the natural consequence of its escape.?

If a situation falls within this rule, then liability is absolute. The rule has been used to impose liability for the escape of water, electricity, gas, oil, fire and explosions.

Liability for damages arising out of the use of dangerous chattels and extra hazardous acts and operations is theoretically not absolute, but the tendency of our Courts has been to impose such a high standard of care that in fact the liability does become absolute.

We refer you again to the Donoghue v. Stevenson where Lord MacMillan stated:

1 [1932] A.C. $562,580$.

2 Palsgraf v. Long Island Railroad Company (1928), 248 N.Y. 339; 162 N.E. 99. per

Cardozo. J. A good example of this princists on a man carrying a pound of butter as compared to a pound of dynamite. Reference should also be had to Dominion Natural Gas v. Collins, [1909] A.C. 640 .

Collins, [1909] A.C. 640. also be had to Bolton v. Stone, [1951] A.C. 850 .

1961 A.C. 388.

6 1866] L.R. 1 Ex. 265, affd. [1868] L.R. 3 H.L. 330.

7 Id., at 279-280. 
The exceptional case of things dangerous in themselves or known to be in a dangerous condition has been regarded as constituting a peculiar category. ... . I regard this type of case as a special instance of negligence where the law exacts a degree of diligence so stringent as to amount to practically a guarantee of safety. 8

The category of dangerous chattels and dangerous operations was commented on in Beckett v. Newals Insulation Company, where it was stated:

The true question is not whether a thing is dangerous in itself, but whether, by reason of some extraneous circumstances, it may become dangerous. There is really no category of dangerous things; there are only some things which require more and some which require less care. ${ }^{9}$

\section{THE LIABILITY OF AN EMPLOYER FOR ACTS OF HIS INDE- PENDENT CONTRACTOR.}

We might first refer to some general authorities dealing with factors which have been referred to time and time again by the Courts in deciding whether or not the relationship of an employer-independent contractor exists. In Salmond on Torts we find the following statement:

This may be put in another way by drawing a distinction between one employed under a contract of service (a servant) and one employed under a contract for services (an independent contractor). "A distinction between a contract for services and a contract of service can be summarized in this way: In the one case the master can order or require what is to be done, while in the other case he cannot only order or require what is to be done but how itself it shall be done.' This right of control has always been accepted since the time of Baron Bramwell as the essential mark of a contract of service. Other marks of a contract of service are (i) the master's power of selection of his servant, (ii) the payment of wages or other remuneration, (iii) the master's right of suspension or dismissal. On the servant's side there is an obligation to present himself for work at the agreed time, to obey all reasonable directions, to continue to work for the agreed period, and also to indemnify his master against liability to third parties. Yet it cannot be doubted that a contract of service may exist although one or more of these elements is absent altogether or present only in an unusual form. 10

\section{In Halsbury's Laws it is stated as follows:}

An independent contractor on the other hand, is entirely independent of any control or interference in merely undertaking to produce a specified result employing his own means to produce that result.11

Turning now to the general principle, it will be appreciated that in most cases an employer is not responsible for the torts of his independent contractor. For example, we refer you to Johnston v.Mills. ${ }^{12}$

The Supreme Court of Canada stated the same rule in St. John v. Donald. In this case Anglin, C. J. C. stated:

.... it is, no doubt, the general rule that the person who employs an independent contractor to do work in itself lawful and not of a nature likely to involve injurious consequences to others is not responsible for the results of negligence of the contractor or his servants in performing it. The employer is never responsible for what is termed casual or collateral negligence of such contractor or his work in the carrying out of the contract; . . . 18

This principle is of special interest to persons concerned with the oil industry, in that most drilling contracts contain a clause purporting to make the driller the independent contractor for all purposes and in all

8 Ante, n. 1, at 611-12.

[1953] 1 W.L.R. 8 .

10 Salmond on Torts, 14th ed., at 649-650.

11 Halsbury's Lavos 146, (3d ed. Simonds 1955).

12 Johrston v. Mills (1917), 37 D.L.R. 767 .

13 [1926] 2 D.L.R. 185. Reference should also be had to Honeywill v. Larkin, [1934] 1 K.B. 191, 196. 
situations. The question as to whether this sort of provision is effective will be discussed in this paper with regard to question 3 enumerated above.

D. EXCEPTIONS TO THE RULE THAT AN EMPLOYER IS NOT LIABLE FOR ACTS OF HIS INDEPENDENT CONTRACTOR.

There are certain particular circumstances when the employer is liable for acts which are done by a person hired by him, even though that person is an independent contractor.

There is no need to refer to all of the exceptions, but we should refer to the following in relation to the questions to be dealt with in the paper:

(a) Rylands v. Fletcher (Ante).

(b) Extra hazardous activities and dangerous chattels.

Prior to discussing the exceptions set out above, we should point out that the general principle that an employer is not responsible for his independent contractor, does not excuse an employer from his own negligence in telling the contractor what work to do or where to do it.

The mere fact that the act complained of is one delegated to an independent contractor is not a defence to an action for negligence against the employer. For example, in the oil industry if an operator hires an independent driller and tells him to drill at a particular location, where the operator knows or should have known that a gas pipeline is situated, and that pipeline explodes as a result of the drilling, then the operator himself will be liable for his own negligence despite the fact that an independent contractor did the work.

Fridman in his book, The Law of Agency, states this principle as follows:

In the first place it is important to notice that the liability for independent contractors is really liability for improper performance by the employer himself of the duty upon him. His liability does not depend upon the nature of the powers entrusted to the independent contractor for he has not really given the contractor any powers. He has merely employed the contractor to perform something for him, not to represent him legally, but to act in a certain way, e.g. build a bridge or road. Hence the employer's liability results from the contractor's misfeasance in the course of performing a contract, not in the course of exercising powers. 14

Turning now to the exceptions to the general rule set out above, we will first deal with the rule of strict liability laid down in Rylands v. Fletcher. The rule laid down by Blackburn, J. has been set out above. For our purposes, it is not necessary to go into a detailed discussion of the rule at this time.

It is sufficient to point out that the case itself arose where the owners of land employed independent contractors, who were apparently competent, to construct a reservoir on their land to provide water for a mill. In the course of the work, the contractors came upon some old shafts and passages. The shafts connected with the mines of a neighbour of the owner of the land, although no one suspected this, for they appeared to be filled with earth. The contractor did not block them up, and when the reservoir filled with water it burst through the old shafts and flooded the neighbour's mines. It was found as a fact that the owner of the land was not negligent, yet the contractors had been. The Court held the owner of the land liable even though there was no fault on his part.

14 Fridman, The Law of Agency, at 199. 
Of the two exceptions to the rule that an employer is not liable for the acts of his independent contractor, the exception based on inherently dangerous chattels and extra hazardous acts is of more interest to persons concerned with the oil industry. In St. John v. Donald, Anglin, C. J. C., stated this exception as follows:

The employer is never responsible for what is termed casual or collateral negligence of such a contractor or his workmen in the carrying out of the contract; and it is not universally true that he is responsible for injury occasioned by improper or careless performance of the very work contracted for; he is not so where the work is not intrinsically dangerous and if executed with due care, would cause no injury, and the carrying out of it in that manner would be deemed to have been the thing contracted for. His vicarious responsibility arises, however, where the danger of injurious consequences to others from the work ordered to be done is so inherent in it that to any reasonably well-informed person who reflects upon its nature the likelihood of such consequences in so doing, unless precautions are taken to avoid them, should be obvious, so that were the employer doing the work himself his duty to take such precautions would be indisputable. That duty imposed by law he cannot delegate to another, be he agent, servant or contractor, so as to escape liability for the consequences of failure to discharge it. That, I take it, is a principle applicable in such a situation whatever be the nature otherwise or the locus of the work out of which it arises.15

\section{E. OCCUPIERS' LIABILITY}

Before beginning a general discussion of occupiers' liability, we must set out our conclusion as to the liability of the operator and the liability of the contractor for injuries suffered by persons who are not on the premises. We are of the opinion that if $\mathrm{D}$, in carrying out an inherently dangerous act, is negligent, and if by that negligence some person off the premises is injured, then both $\mathrm{D}$, and $\mathrm{C}$, his employer, will be liable for those injuries. The next question which must be considered is whether or not the fact that the injured party is on the land occupied by the employer changes that party's position in the eyes of the law with regard to potential rights of action against the employer-occupier?

We have assumed for the purposes of this paper that the operator, and not the driller, is the occupier of the premises and as such, reference should first be made to the liability of a non-occupier to persons visiting the premises. The primary question that arises is whether or not an independent contractor carrying on an operation on the land of another has the same defences available as the occupier would have with respect to loss suffered on the premises by other persons coming on to the land.

The leading case on the subject appears to be Billings v. Riden ${ }^{16}$ where the House of Lords held that an independent contractor, not in possession of the premises, owed a duty "to take reasonable care for the safety of visitors" and further held that the independent contractor's duty was not co-extensive with that of the occupier of the premises.

Another English case dealing with the problem was Buckland v. Guildford $\mathrm{Gas}^{17}$ where a thirteen year old girl, who was trespassing on the land of a farmer, climbed a tree and came into contact with the Defendants' high-voltage electric wires which were hidden in the foliage. In holding the Defendants liable, the Court relied on the classic test of Lord Atkin as to whether or not the Defendants had been guilty of

18 [1926] 2 D.L.R. 185, 191. Reference should also be had to The Pass of Ballater, [1942] at 112; Honeyroill v. Larkin, [1934] 1 K.B. 191, at 196 and 197; Bennett v. Imperial Oil Limited (1961), 28 D.L.R. (2d) 55

$16[1958]$ A.C. 240.

$17[1949] 1$ K.B. 410 . 
negligence and held that the fact that the child was a trespasser as regards the farmer did not constitute a defence which the gas company could take advantage of. It should also be noted that the Court distinguished the case of Robert Addie v. Dumbreck. ${ }^{18}$

It is our opinion that the liability of persons carrying on activities on land in possession of another is based on the broad principles of negligence as laid down in Donoghue v. Stevenson. Support for this principle is found in a number of recent cases, and in the writings of leading authorities on the subject. ${ }^{19}$

Questions 5 and 6 (Ante), dealing with an invitee and a trespasser, respectively, raise the problem of the liability of an occupier-employer for the results of activities conducted on his premises. As stated above, we have assumed that the operator is the occupier of the premises within the meaning of the term as used in the cases. Most of the cases and many textbook writers ${ }^{20}$ dealing with occupiers' liability treat the duty owed to a person visiting the premises as one in relation to the state of the premises. However, there appears to be a tendency in some recent decisions for the Courts to extend the rules relating to an occupier's liability to include liability not only for the state of the premises but for activities conducted on those premises. ${ }^{21}$ These decisions appear to have served the purpose of giving a remedy to the Plaintiff in particular circumstances.

We are of the opinion that, while the trend to equate the state of the premises with activities conducted thereon may provide a remedy in certain circumstances, such an approach to the problem limits and restricts the general development of the law along the lines of the broad principles of negligence. There can be no question that this area of the law is in a state of flux and as the Supreme Court of Canada has indicated,22 it is prepared to move with the times. We would, therefore, expect and hope that we can look forward to bold steps in this respect if and when the Supreme Court of Canada is given an opportunity to deal with this question.

If one can conclude that the law will develop along the lines set out above, then an occupier's liability, with respect to activities conducted on the premises, will be determined by the ordinary principles of negligence. If the activities are conducted by a servant, then the occupier will be vicariously liable. On the other hand, if the activities are conducted by an independent contractor, then the occupier will not necessarily be liable; the rules discussed above in relation to an employer's liability and the exceptions thereto would apply.

Mention should also be made of the position of a trespasser, with respect to the question of an occupier's liability for operations being carried out on the premises. Recent decisions indicate that it will be difficult to overcome the effect of the categories of occupier's liability, ${ }^{23}$ but again this area is open for a final pronouncement on the part of the

16 [1929] A.C. 358.

10 Fleming on Torts, 3d ed., at 439; Salmond on Torts, 14th ed.. at 413; Niron v. Manitoba Power (1960), 21 D.L.R. (2d) 68; LeBlank v. The City of Moncton (1962), 33 D.L.R. (2d) 395.

20 Salmond on Torts, 14th ed., c. 12; Fleming on Torts, 3d ed., c. 19.

21 Lehnert v. Nielson, [1947] 2 W.W.R. 25; Fleming on Torts, 3d ed., at 405.

22 Hillman v. Macintosh, [1959] S.C.R. 384, wherein the Supreme Court to all intents and purposes overruled Fairman v. Perpetual Investment, [1923] A.C. 74.

23 Stanton v. Taylor, Pearson \& Carson, (1965), 54 W.W.R. 449;Com'r. for Rys. v. Quinlan, [1964] 1 All E.R. 897. 
Supreme Court of Canada and we are inclined to the view that the ordinary rules of negligence should apply.

We now propose to apply the principles set out above to discuss and to solve each of the questions set out at the start of this paper.

\section{(1) D NOT NEGLIGENT-INHERENTLY DANGEROUS ACT.}

On the basis that $D$ is an independent contractor throughout, and on the basis that he was not negligent at anytime whatsoever, it is our opinion that with regard to damage to the hole and the rig, D will not be liable in the absence of negligence.

In United States jurisdictions absolute liability attaches to persons dealing with or performing what can be termed ultra-hazardous activities. In that regard we refer you to the American Restatement of Torts:

One who carries on an ultra-hazardous activity is liable to another whose person, land or chattels the actor should recognize as likely to be harmed by the unpreventable miscarriage of the activity for harm resulting thereto from that which makes the activity ultra-hazardous, although the utmost care is exercised to prevent the harm. ${ }^{24}$

Although it is certainly not unforeseeable that such law could be brought into this jurisdiction by way of statute sometime in the future, we are of the opinion that, at present, despite the turn toward strict liability, the law will still not attach liability to a person carrying on ultrahazardous activities unless there is some indication of negligence.

This being the case, it is our opinion that no liability will attach to $D$ for the damage to the hole and rig. We should refer again, however, to our comments regarding inherently dangerous chattels and activities and the fact that the standard of care in such situations becomes so stringent as to almost impose strict liability.

Examining the question from the point of view of $\mathrm{C}$, the operator who hired $\mathrm{D}$, one must come to the same conclusion. Not only is it the general rule that an employer cannot be liable for the acts of his independent contractor, but how can an employer be liable if the contractor himself cannot? We have assumed for purposes of posing this question that the employer himself is not guilty of any negligence in directing $\mathbf{C}$ to carry out the ultra-hazardous activity.

With regard to the third party's equipment which is located nearby (we have assumed somewhere off the premises), we are of the opinion that the principle enunciated in Rylands v. Fletcher is applicable. It will be appreciated that to fall within the Rylands v. Fletcher rule there must be a non-natural user of the land, something brought onto that land likely to do mischief if it escapes, and an escape.

We are of the opinion that bringing a rig and drilling equipment onto land amounts to a non-natural user so as to fall within the principle set out above. The Privy Council, in Rickards v. Lothian stated:

It is not every use to which land is put that brings into play that principle. It must be some special use bringing with it increased danger to others, and must not merely be the ordinary use of the land or such a use as is proper for the general benefit of the community. ${ }^{25}$

We are also of the opinion that the explosion which presumably caused

24 S. 519 .

25 [1913] A.C. 263. 
damage to the third party's equipment by forcing either air or debris outward would amount to an escape within the meaning of the rule. ${ }^{2 \theta}$

An interesting question presents itself as to whether or not it is arguable that to fall within the rule it is necessary that the dangerous substance brought onto the land be the thing which escapes and not air or shock waves from an explosion emanating from that dangerous substance? There does not appear to be any authoritative statement covering this point and we would refer you to the cases listed below for examples of situations in which the rule in Rylands v. Fletcher has been applied. ${ }^{27}$

Assuming that the rule does apply, we are of the opinion that only the operator $\mathrm{C}$ will be liable since $\mathrm{D}$ does not have sufficient possession of the land in question to bring any dangerous substance onto it and fall within the rule.

\section{(2) INDEPENDENT CONTRACTOR, D, NEGLIGENT}

It is obvious that if the independent contractor, $D$, is negligent, then he himself will be liable under the general principles enunciated above for all foreseeable damage- which results from his acts. However, the interesting question which arises and which has already been partially discussed is whether or not operator C, D's employer, will also be liable for his negligence.

As stated above generally an employer is not responsible for the acts of his independent contractor. However, the exception which is relevant in this case is that drilling contractor $D$ is carrying out what can be termed an extra hazardous or inherently dangerous activity. Where the projected work involves a high risk calling for special precautions, the employer himself must ensure that they are taken for the sake of those within his foreseeable range, and cannot renounce that responsibility through employing an independent contractor. In such situation the employer "has not merely a duty to take care but a duty to provide that care is taken." 28

A more recent Canadian case invoking the same principle was Wilby v. Savage, ${ }^{29}$ where the New Brunswick Appellate Court stated that where the work to be done involves the use of material and instruments which are in themselves hazardous then the employer of the independent contractor is bound equally with him by an inescapable duty not only to take care, but to provide that care is taken.

Applying the above set out principles, both $C$ and $D$ would be responsible for damage flowing from the negligent acts of $D$ while carrying out an inherently dangerous act.

26 See J. P. Porter Company v. Bell, [1955] 1 D.L.R. 62.

27 Aikman v. Mills \& Company, [1934] 4 D.L.R. 264-contractor dolng blasting work in Detrolt River held llable for structural damage caused by vibration from blasts; Bower Detroit River held lable v. Richardson Construction, piles by method which caused vibration and was held ons on his land nor can they be 2 D.L.R. 665-a man cannot bring or collect vibrations on his land, nor can piltiterrt $v$. sald to escape, neither are they noxious or danserous in their own nature; ; lititerr v. Northern Construction, [1930] 4 D.L.R. $731-$ contractor using dynamite held liable
injury caused by vibrations and falling stones emanating from his blasting operations.

28. The Pass of Ballater, [1942] P. 112, 117.

29 [1953] 4 D.L.R. 319. The case cites with approval the Honeywill case (Ante), The Pass of Ballater (Ante), and Aga Heat v. Brockville, [1945] S.C.R. 184. 
(3) WHAT CONDITIONS ARE ESSENTIAL TO ENSURE THAT D WILL BE ACCORDED THE STATUS OF AN INDEPENDENT CONTRACTOR?

We are of the opinion that the following factors, enumerated by McCardie, J. in Performing Rights Society v. Mitchell \& Booker, ${ }^{80}$ are relevant in deciding whether or not any given workman is an independent contractor or servant of the employer:

(a) Most important, the nature and degree of detailed control over the person alleged to be a servant.

(b) Who has the power of dismissal and the manner in which the contract may be terminated.

(c) The circumstances under which payment of the reward may be withheld.

(d) The magnitude and nature of the task undertaken, the magnitude of the contract amount, and the manner in which it is to be paid.

The most important factor: control, was discussed by the House of Lords in Mersey Docks v. Coggins \& Griffith. ${ }^{31}$ In that case a firm of stevedores had hired a mobile crane and its driver to do certain work for them, subject to a contract that stipulated that the driver of the crane was to be the servant of the hirer. In the course of operating the crane, the driver injured a third party by negligently using his equipment. At the time of the injury the stevedores had the immediate direction and control of the operation of picking up and moving each piece of cargo, but had no power to direct how the crane should be worked or the controls manipulated. The injured party sued the owners of the crane who claimed that at the time of the injury their driver had become the servant of the stevedores, and they were therefore not responsible for him.

The Law Lords held that since the stevedores had no control over how the crane driver actually operated the crane, as distinguished from telling him what he was to do with the crane, then he was in effect still an independent contractor and his own employers were liable for his actions. Viscount Simon, in discussing the problem, stated as follows:

I would prefer to make the test turn on where the authority lies to direct, or to delegate to, the workmen, the manner in which the vehicle is driven. It is this authority which determines who is the workman's 'superior'. ... If the hirers intervene to give directions as to how to drive which they have no authority to give, and the driver pro hac vice complies with them, with the result that the third party is negligently damaged, the hirers may be liable as joint tortfeasors. ${ }^{32}$

Lord Porter dealt with the question of whether or not the contract between the two purported masters had anything to do with the ultimate liability to third parties:

Nor is it legitimate to infer that a change of masters has been effected because a contract has been made between the two employers declaring whose servant the man employed shall be at a particular moment in the course of his general employment by one of the two. A contract of this kind may of course determine the liability of the employers inter se but it has only an indirect bearing upon the question which of them is to be regarded as master of the work when on a particular location. ${ }^{83}$

It would appear that the single most important factor in determining this question is control. It would also appear that the usual

\footnotetext{
30 [1924] 1 K.B. 762

31 [1947] A.C. 1

a2 Id., at 12.

33 Id., at 15.
} 
clause in a drilling contract purporting to create the status of independent contractor at all times and for all purposes is meaningless as regards third parties. The question of control is of special interest to the oil industry, where many drilling contracts make provision for the operator to assume complete control of the rig and drilling operations once any indication is had that the pay zone is being reached.

We are of the opinion that, depending upon the circumstances of each individual case, the assuming of such control could well amount to changing the status of the drilling contractor from an independent contractor to a servant of the operator at the time control is assumed. The American jurisdictions appear to have reached a similar conclusion. We would refer you to Lone Star Gas Company v. Kelly, ${ }^{34}$ where the Texas Commission of Appeals said:

An independent contractor is one whom the employer has no right to control as to the manner in which the work is done, or the means by which it is accomplished. ${ }^{35}$

Keeping the above question in mind, we must now turn to the manner in which control is exercised over the drilling of an oil and gas well and investigate what the Courts have said as to what circumstances create the status of an independent contractor. In an article by Wilmer D. Masterson, Jr. entitled The Legal Position of the Drilling Contractor, ${ }^{36}$ he states that practically every drilling contract provides for inspection of work as it progresses by the operator. He points out that a right to inspect without any right of control does not destroy or affect in any way the status of an independent contractor, and this is true whether the right to inspect accrues after the work is completed, or as the work progresses. He quotes with approval Arkansas Natural Gas Company v. Miller ${ }^{37}$ where it is stated:

The mere retention by the owner of the right to inspect work of an independent contractor as it progresses, for the purpose of determining whether it is com-

pleted according to plans and specifications does not operate to create the relation of master and servant between the owner and those engaged in the work.

This rule is not altered by the fact that the employer may stop work which is not properly done.

It also appears clear that a drilling contract can create the status of independent contractor for some acts in the drilling operation and refrain from doing so as to other parts. For example, the drilling contractor may be an independent contractor as the well is drilled in that the operator maintains little or no control over the operation at that time, and then as the well nears completion, the operator may well assume sufficient control to destroy the previous relationship.

Some of the conclusions set out by Masterson in his article are both interesting and helpful in dealing with what provisions should be inserted into drilling contracts. He suggests as follows:

"1. Define and limit authority of employees to modify the contract, particularly the provisions thereof relating to control of the work;

2. Define which party shall have control at each of the various steps in drilling, fixing liability for damage which may occur at any such step, both as between the parties themselves, and as between them and specialty contractors or other third parties;

3. Provide in detail what machinery shall be used and the method of usethat is make the drilling of a well as safe as a contract can make it. ..."

34 [1932] 46 S.W. (2d) 656 .

${ }_{36}$ The First Annual Institute on Oil and Gas Law (1949), Southwestern Legal Foundation,

36 The First

87 [1912] 152 s.w. 147. 
(4) INHERENTLY DANGEROUS OPERATIONS-DRILLING, TESTING AND COMPLETION.

In Beckett v. Newals Insulation Company, ${ }^{88}$ the Court stated:

The true question is not whether a thing is dangerous in itself, but whether, by reason of some extraneous circumstances, it may become dangerous. There is really no category of dangerous things; there are only some things which require more and some which require less care.

We are of the opinion that drilling operations per se are not inherently dangerous. However, by reason of the risk that during the course of such operations gas under pressure may be encountered at any time, drilling operations are potentially dangerous. The potential is realized and they become inherently dangerous when during the course of such operations gas is encountered. The danger arises from the risk of an uncontrolled release of gas under pressure, ignition, or its poisonous characteristics in some circumstances.

The danger of striking pockets of gas of the ordinary variety or marsh gas is one example of an inherently dangerous act, another example is the use of air in place of a drilling fluid where gas may be encountered. The same danger arises in testing and completion operations. Aside from risks involved in drilling itself there are ancillary sources of risk such as acidizing. Such procedures bring onto the premises a dangerous substance and the risk here is not only in the use but in transportation and storage of such substances.

(5) and (6) OCCUPIERS' LIABILITY

In our earlier remarks we expressed the opinion that a distinction should be drawn between the duty owed with respect to the state of the premises and the duty that arises when operations or activities are conducted on the premises.

With respect to the duty owed to an invitee in relation to risks arising from operations conducted on the premises, in our view, the occupier will be liable in our circumstances when the operations are inherently dangerous and the driller is guilty of negligence. If the driller is negligent and the operations are not inherently dangerous, in our view liability should not attach to the operator.

Turning to the case of the trespasser, certainly there is some doubt that the law will develop as far along the lines set out herein as we have predicted. Fleming states:

But this timely reappraisal, evidently appealing even to English courts, was abruptly caught short by the Privy Council which would brook no such compromise with the old verities, thus dispelling again all sanguine hope of replacing the presently fragmented pattern of legal rules by a more systematic and reformed modern solution. ${ }^{3 \theta}$

If development of the law in this branch does not take place then the occupier will not be liable for mere negligence on the part of the driller even though the act is inherently dangerous.

The driller's liability, which will also be the basis of the occupier's liability if the predicted development in the law takes place, will depend upon evidence to support the conclusion that the driller was or should have been aware of the presence of the trespasser. The risk that a trespasser is present must be substantial and not a mere possibility.

88 [1959] 1 W.I.R. 8.

80 Hleming, The Law of Torts, 3d ed., at 432. 